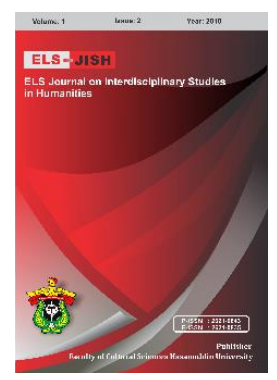

ELS-JISH

ELS Journal on Interdisciplinary Studies on Humanities

Volume 1 Issue 2, 2018

ISSN (print) : 2621-0843

ISSN (online) : 2621-0835

Homepage : http://journal.unhas.ac.id/index.php/jish

\title{
Transitivity and Modality in a Marriage Proposal Skit of English and Makassarese
}

\author{
Nur Wahdaniyah ${ }^{1}$ \\ e-mail: nurwahdaniyah@ymail.com
}

\begin{abstract}
Two languages are never considered to represent the same social reality in similar way sufficiently, especially in conveying the humour. The objectives of this research are to identify the patterns of transitivity and modality used to represent the humour in marriage proposal skit of English and Makassarese and also to explain the way of English and Makassarese humour maintain power of relationship in marriage proposal skit. This research was conducted by using Critical Discourse analytic approach of Fairclough and Halliday's Theory particularly in transitivity and modality system of both English and Makassarese. The results of this research show that Halliday's theory cannot cover all Makassarese data, especially in dividing process of functions in the level of ideational and interpersonal meaning of Makassarese data. In fact, in building their relationship through humour, English speakers tend to use many relational processes which they asked about the identity of their interlocutor and also use many deontic modality (desirability, obligation, and permission). In Makassarese data, speakers tend to use many material processes that they can know what happened with their interlocutor and what is their interlocutor doing. And also they use lack of deontic modality with no obligation category.
\end{abstract}

Keywords: Transitivity, Modality, Humour, Participants' relationship, Proposal marriage skit.

How to cite: Wahdaniyah, N. (2018). Transitivity and Modality in a Marriage Proposal Skit of English and Makassarese. ELS Journal on Interdisciplinary Studies in Humanities, 1 (2), 117-125.

\section{Introduction}

The language habits of the group are built up from the 'real world' unconsciously. Two languages are never considered to represent the same social reality in similar way sufficiently. It means that different society has the distinctive world. Sapir in Duranti (1997), proposed that condition as linguistic relativity in communication. Indeed, languages have their own uniqueness, especially in conveying the humour. In doing communication people sometimes face the humour situation. Humour likes a knife, it has two sides where in one social situation, humour can escalate the conflict, but in the other side, it can reduce the conflict. In fact, people use the kinds of humour to express their ideology and also through humour, they show their power (Lockyer \& Pickering, 2008). There is a complex interrelation between humour and context where any account of humour must take into account of the cultural context (Norrick in Gunther, 2003). So, shared knowledge about cultural values is the essential prerequisite for humour to occur. In fact, socio-cultural aspects of humour can be addressed by the superiority theories (Rahimi \& Riasati, 2011). In other words, the power of relationship can be identified in communication by looking out

${ }^{1}$ Hasanuddin University 
the socio-cultural aspects of humour used by the speakers. In 2014, the researcher has conducted the field research about Ganrang Bulo in Makassarese culture, and fortunately, she watched and recorded the marriage proposal skit's video which is performed by the two singers of Ganrang Bulo (pakelong). At that time, she realized that in doing communication, the speakers of skit (comedians) used some kinds of humour and they made the audiences laugh. The speakers also showed their power by using those humour and then used them to build their relationship. Being an English language student, the researcher always looks out for resources that would connect English and Makassarese culture as her own local culture, so, the researcher decides to conduct the research about The Affect Of Humour On Participants' Relationship In A Marriage Proposal Skit Of English And Makassarese : A Comparative Study.

There are some previous researches that analyzed about the relation between humour, CDA approach and Halliday's theory, such as in Inayah (2015), who examined about how to figure out power construction in Buginese greetings in Soppeng regency social community which is not found in English greetings and also explained how the speakers constructed power while using jokes in Buginess and English greetings. Wahdaniyah (2015), with the title The Intertextuality of Kelong in Siru dance of Ganrang Bulo Performance, she emphasized about kelong as discourse and used the textual meaning of Halliday's theory in analyzing kelong text. Adawiah (2014), conducted a study with the title Modalities in Political Debate Discourse, she explained about political debate as a spoken discourse where she used systemic functional grammar theory to find out the modalities that used by the speakers of political debate in America and Indonesia. Bukhari and Xiaoyang (2013), conducted the research which linked the critical discourse analytic approach with some models of critical discourse analysts as the educational research tool. Then Zelizer (2010), in his study with the title Laughing Our Way to Peace or War: Humour and Peacebuilding, he explained how humour can be a conflict resolution and shown an analytical model regarding the role of humour in peacebuilding around the war areas. In his study, he also explained some kinds of humour and through which modalities they are expressed.

Starting from the point that each cultures has the way to convey the humour in every kinds of social situation (Krikmann, 2006), the researcher compares the transcription of skit's data in marriage proposal process from Makassarese and English in this research. She wants to know the differences and similarities in maintaining the power of relationship between the speakers from both data and also the way of humour which is used by the speakers to show the power of relationship in both data. The researcher uses Critical Discourse Analysis's framework of Fairclough in analyzing the data. Breeze (2011) and Unger (2016), in explaining the interdisciplinary of CDA emphasized that Fairclough (1995), provided the way in analyzing discourse critically by using three dimensional frameworks, they are; text analysis, processing analysis, and social analysis. Through this framework, the researcher uses it to cover the data and then links it to Halliday's theory in Halliday \& Matthiessen (2004), to find out the linguistic features, especially modality and transitivity system in representing the humour by the speakers of skit (comedians) and also relate them with the power of relationship of their speaking process. Based on Zelizer (2010), the reason in analyzing transitivity and modality system of both skit's data is because the researcher wants to render the content of humour that conveyed by the speakers and to interpret the attitude (motivation and tone) of speakers in conveying their humour. Finally, this research is designed to 1) identify the patterns of transitivity and modality used by the participants to represent the humour in marriage proposal skit of 
English and Makassarese and 2) explain the way of English and Makassarese humour work to maintain participants' relationship in marriage proposal skit.

\section{Method}

This research uses descriptive qualitative method in analyzing process of data. In fact, Tracy (2013), emphasized that our daily activities are actually influenced by qualitative method, such as -when we asked questions, listen to stories, participate on meetings, gossip, watch others activities, and check our text message. When we conducted those activities, then we gathered qualitative data about social phenomena around us. Through doing those activities, we also learned about the others culture, experiences, and even their sense of humour

\subsection{Source of Data}

This research is a comparative study in which the researcher compares data of video recording about marriage proposal skit on Makassarese that was conducted as the part of Ganrang Bulo performace in marriage ceremony on June 2014 and data from marriage proposal skit on English that was gathered from published video on youtube with the title "Brian \& Jenny Wedding Reception - Family Skit and Song".

\subsection{Data Collection}

For collecting research data, the researcher uses some procedures by using Spradley methods (1980), in participant observation, especially to gather Makassarese data, include; 1) Observation: The researcher conducts it to identify the social situation in both data of English and Makassarese. 2) Note Taking: In the process of observation, the researcher takes down all notes to make clear all the information which she finds in the field. This technique is conducted especially in observation process of Makassarese skit's performance. 3) Recording: In gaining skit's data of Makassarese, the researcher conducted field research in which she made a video recording when the speakers of skit (comedians) performed their funny skit. 4) Downloading: Skit's data of English are gained by downloading from youtube where the researcher identified some variables of assessment that made the English video appropriate with skit's video of Makassarese. The variables of choosing English video's skit are -the content of video (about marriage proposal process), the age of speakers and the number of speakers in that video.

\subsection{Data Analysis}

After collecting data, the researcher uses some steps on analysis as follows: 1) Watching the skit video of English and Makassarese and transcribes them to find out skit's data. 2) Classifying both data per exchange to show the maintaining process of power of relationship. 3) Then, analyzing both skit's data by using CDA's framework of Fairclough, then in the part of text analysis, she identifies the patterns of transitivity and modality after classifying data into clauses by using Halliday's theory 4) After that, interpreting the using of humour by speakers of skit in relating with the patterns of transitivity and modality. 5) Finally, explaining the power of relationship of speakers by looking the relation between socio-cultural aspects of humour and the patterns of transitivity and modality.

\section{Findings}

English skit's data show that in transitivity pattern the relational process type exists in 8 exchanges as the significant process type used by the speakers, and in the second position is verbal process which its presence in 7 exchanges, then material and mental 
process, both of them exist in 6 exchanges, and also behavioral process in 2 exchanges and the last is existential process in only 1 exchange as shown on the table 1 below:

Table 1. Total of Process Types and Their Occurrence in All Exchanges of English Data

\begin{tabular}{ccc}
\hline $\begin{array}{c}\text { Process Types of English } \\
\text { Data }\end{array}$ & $\begin{array}{c}\text { Total of Process Types' } \\
\text { Occurrence }\end{array}$ & $\begin{array}{c}\text { Exchange's Total of } \\
\text { Process Types' } \\
\text { Occurrence }\end{array}$ \\
\hline Material process & 13 & in 6 exchanges \\
Verbal process & 9 & In 7 exchanges \\
Mental process & 12 & In 6 exchanges \\
Behavioral process & 2 & In 2 exchanges \\
Relational process : & 20 & In 8 exchanges \\
- Attributive/Possessive & 9 & In 1 exchange \\
- Identifying & 4 & \\
Existential process & &
\end{tabular}

While in modality, data of English skit show that from 69 clauses, there are around 17 clauses that have modality. the researcher identifies the category of modality based on the Fowler's postulate to this English skit's data where the first significant category is validity in 7 occurrences, then desirability in 6 occurrences, and then obligation in 2 occurrences, and the last is predictability and permission, both of them are in 1 occurrence as shown on the following table:

Table 2. Modality Pattern on English and Makassarese

\begin{tabular}{|c|c|c|}
\hline Skit's Data & $\begin{array}{c}\text { Palmer's Category of } \\
\text { Modality }\end{array}$ & $\begin{array}{c}\text { Fowler's Category of } \\
\text { Modality }\end{array}$ \\
\hline & Epistemic : 8 & $\begin{array}{ll}\text { Validity } & : 7 \\
\text { Predictability }: 1\end{array}$ \\
\hline English & Deontic $: 9$ & $\begin{array}{ll}\text { Permission } & : 1 \\
\text { Desirability } & : 6 \\
\text { Obligation } & : 2\end{array}$ \\
\hline & Epistemic : 9 & $\begin{array}{ll}\text { Validity } & : 7 \\
\text { Predictability }: 2\end{array}$ \\
\hline Makassarese & Deontic : 3 & $\begin{array}{ll}\text { Permission } & : 2 \\
\text { Desirability } & : 1 \\
\text { Obligation } & : 0\end{array}$ \\
\hline
\end{tabular}

In Makassarese skit's data, Halliday's theory cannot cover them in some clauses because one word of Makassarese can have two functions directly. For example, in clauses number 2 and 3 of Makassare data below;

B :Oi, ada -ja', lailahaillallah

Hei, here I , lailahaillallah

Hei, I'm here, lailahaillallah

\section{A: katte anjo paeng,}

You that apparantly

That's you apparently 
The word ada of clause 2 in Makassarese has two functions as circumstance of location and as process existential in the level of ideational meaning. And also the word anjo in clause 3 which also has two functions as identified (subject) and as process relational identifying on table 3 and 4 in.

Table 3. Clause number 2 of Makassarese data

\begin{tabular}{lll}
\hline Oi, Ada & -ja' \\
\hline $\begin{array}{l}\text { Circumstance } \\
\text { location }\end{array}$ & of Process existential & Existent \\
\hline
\end{tabular}

Table 4. Clause number 3 of Makassarese data

\begin{tabular}{lll}
\hline Katte & Anjo & \multicolumn{1}{c}{ paeng, } \\
\hline Identifier & Identified & $\begin{array}{l}\text { Pro. relational } \\
\text { identifying }\end{array}$ \\
\hline
\end{tabular}

These data show that Halliday's theory cannot fit in all data of Makassarese, especially in dividing process of function in ideational meaning. In fact, even Halliday's theory cannot fit in all Makassarese data, but this theory gives valuable help for writer in analyzing process of transitivity and modality pattern.

Table 5. Total of Process Types and Their Occurrence in All Exchanges of Makassarese Data

\begin{tabular}{|c|c|c|c|}
\hline $\begin{array}{lr}\text { Process } & \text { Types } \\
\text { Makassarese' Data }\end{array}$ & of & $\begin{array}{l}\text { Total of Process } \\
\text { Types' Occurrence }\end{array}$ & $\begin{array}{l}\text { Exchange's } \\
\text { Process } \\
\text { Occurrence }\end{array}$ \\
\hline Material process & & 31 & in all exchanges \\
\hline Verbal process & & 8 & In 5 exchanges \\
\hline Mental process & & 15 & In 6 exchanges \\
\hline Behavioral process & & 2 & In 2 exchanges \\
\hline \multicolumn{4}{|l|}{ Relational process : } \\
\hline Attributive/Possessive & & 7 & In 9 exchanges \\
\hline Identifying & & 12 & \\
\hline Existential process & & 3 & In 2 exchanges \\
\hline
\end{tabular}

Furthermore, The result of analyzing Makassarese skit's data shows that the most significant occurrence of process type is material process which is around 31 occurrences, then relational process types which are about 19 occurrences, and then mental process type which is in 15 occurrences, the next is verbal process that is around 8 occurrences, and also existential process is around 3 occurrences, and the last is behavioral process that is in 2 occurrences (see table 5 in appendices). While in modality pattern, the researcher identifies about 12 clauses which contain modality from the total 78 clauses in which validity is the significant category rather than the others which is around 7 
occurrences, then permission and predictability, both of them are in 2 occurrences, and then desirability is in 1 occurrence (see table 2).

\section{Discussion}

This research shows that both English and Makassarese skit's data have the similarity in social situation and the speakers also talked about the same issue that is marriage proposal process. In fact, the differences of socio-cultural background of the speakers in English and Makassarese skit give the different effect in the process of conveying their humour and also building their relationship. The differences between them are identified by the patterns of transitivity and modality of both data. Indeed, Zelizer (2010), explained that some aspects in conveying the humour are -the content of the message, the motivation and tone of speaker, and the way of receiver in interpreting the message (humour) from the speaker. By analyzing transitivity system (the processes) of skit's data, the researcher can identify the content of message that contains humour, while by analyzing the modality system of skit's data, she can identify the motivation and tone of speakers to convey their humour, and then she also divides the data into exchanges to see the interaction process between the speaker and receiver of humour.

Indeed, both English and Makassarese data show the similarity in the third and fourth position of process type, they are - mental and verbal process type. While for the first and second position of their process type are different. The researcher interprets that the reason of this difference is because the effect of speakers' cultural background in which influenced the content of their message in conveying the humour. Indeed, in English skit, the first position of process type is relational and the second is material. English speakers tend to use significant number of relational process type rather than material process type in their interaction because they talked about the bridegroom's background, such as his original (nationality), his work, and also the reason to love his bride. Most of the content in English skit is about the process of being. In other word, because the social situation of English speakers is in marriage proposal process, they fostered the relationship between them more deeply by breaking the ice through their humour.

In other hand, Makassarese data show that the first position of process type is material and the second is relational process type. Makassarese speakers use the significant number of material process type because their orientation is to talk about the bride's need and what the bridegroom's family should do to fulfill all the needs of bride. The data show many material process types in all clauses. In other word, to convey the speakers' humour, 'the process of doing and happening' is expressed by them in significant number. Interestingly, although English and Makassarese data are in the similar social situation which is initial part of marriage, both data show the difference in the pattern of their transitivity. Normally, at this kind of social situation, the speakers commonly use relational process type rather than material process type. But, the socio-cultural background of Makassarese's speakers influences to the use of many material process types in their interaction, even in conveying their humour.

By using Fowler (1985) and Palmer's postulate (2001), the researcher finds out that there are similarity and difference of modality's pattern between English and Makassarese skit's data. The almost similar number of epistemic modality in both data explains that English and Makassarese speakers prefer to play their attitude toward the truth value of a proposition when they conveying their humour, specifically in validity and predictability which are covered on epistemic modality's category. English and Makassarese speakers 
use validity in identical number in their interaction process where they try to play the intensity of their confidence about a proposition to their receiver of humour, for example toward the adverbs - really, just, only, probably in English skit, while in Makassarese skit's example toward mi which means just, -ji which means only, and tojenna which means actually. In predictability, the speakers of English show that they use it in once and the speakers of Makassarese that they use it in twice which English speaker expressed it through modal could while Makassarese speaker used modal barang and bara' which mean may. The researcher interprets that in conveying humour, they used predictability to figure out their prediction about something to their receiver.

In deontic modality's category, both data show the extremely difference in the number of occurrence where English data have more deontic modality rather than Makassarese data. It shows that English speakers prefer to talk about the events which are not actualized rather than Makassarese speaker in conveying their humour.

Specifically in permission, English speaker used it once and Makassarese speakers used it twice. Actually, the difference is not much in which both speakers of English and Makssarese do not prefer to use many permission modals in their interaction. Furthermore, Fowler in Lillian (2008), explained that obligation and permission modals can be the assessment to identify the superior position in a text, because their relation with power is very obvious, even the other three categories also show the authority. In this case of permission, the one who is in the superior position has power to allow or forbid his interlocutor to do something. The superior has more chance to initiate the humour, such as in English skit, speaker $B$ as the person who always initiates humour which is responded by speaker $A$. In Makassarese skit, speaker B also has superior position rather than speaker $A$, but both of them have the same number in initiating humour.

In desirability, the difference between English and Makassarese skit is seen very clear which English speakers used many desirability to convey their humour rather than Makassarese speakers. In fact, by looking out desirability modals in the skit, the speakers who have an authority can be identified because their interlocutor will try to convey his desire to them. In English skit, speaker A conveyed his humour through many desirability modals to speaker B. while in Makassarese skit, desirability only occurs in once which is used by speaker A. In obligation, English and Makassarese skit show a difference where in English, obligation occurs twice while in Makassarese, there is no obligation. The researcher identifies that in English skit, speaker B used obligation to show that he has superior position rather than other speakers. However, he used it to control the other speakers in conveying their excessive humour because they are in the process to build their relationship in marriage proposal's social situation.

Furthermore, this research emphasizes that from the finding, actually Halliday's theory cannot cover all Makassarese data, especially in dividing process of word's function in the level of ideational and interpersonal meaning of Makassarese. She finds out that there are some clauses have one word that represents two functions at once, for example in clause number two, the word ada represents the function as circumstance of location and the function as process existential. And also, in clause number 3, the word anjo which represents the function as identified (subject) and process of relational identifying (finitepredicator). The other case of Makassarese language is the position of process (finite) in a clause can be before and after the predicator, for example in the clause number 14 and 26 which the clauses of Makassarese data show the position of process (finite) after the predicator. These data show that actually Halliday's theory cannot cover the analyzing 
process of Makassarese data specifically in the level of ideational and interpersonal, but generally this theory serves a valuable help in the process of analyzing data, particularly both English and Makassarese skit's data. In fact, to conduct the analysis of Makassarese data, the context that is built between the speakers helps the researcher to interpret the patterns of transitivity and modality of Makassarese data.

\section{Conclusion}

As mentioned in the process of analyzing data, Halliday's theory cannot cover all Makassarese data, especially in dividing process of functions in the level of ideational and interpersonal meaning of Makassarese data. In fact, In building their relationship through humour, English speakers tend to use many relational processes which they asked about the identity of their interlocutor and also use many deontic modality (desirability, obligation, and permission) which show their superior position and authority, although this modality is used as the controlling tool in their interaction. While Makassarese speakers tend to use many material processes that they can know what happened with their interlocutor and what is their interlocutor doing. And also they use lack of deontic modality with no obligation category. This shows that they emphasize the same position in initiating their humour. Indeed, this research shows the universality of Halliday's theory in Makassarese skit and tries to render how speakers build their relationship through humour by analyzing the patterns of transitivity and modality used by them. The researcher considers that the research about the way of humour as a tool of relationship-building or peace-building is quite limited, even the exploration about humour through CDA approach and Halliday's theory is more limited rather than other approaches in linguistics study. Finally, the researcher hopes that the next researchers can find out the new intention in humour's exploration by using CDA approach, particularly in their vernaculars.

\section{References}

Adawiah R. (2014). Modalities in political debate discourse. Makassar: Hasanuddin University.

Breeze R. (2011). Critical discourse analysis and its critics. International pragmatics association, Spain: University of Navarra.

Bukhari N. S. \& Xiaoyang W. (2013). Critical discourse analysis and educational research. Journal of Research \& Method in Education, 3(1). China: Institute of Education Tsinghua University.

Duranti A. (1997). Linguistic anthropology: a reader. Malden, Massachusettes: Blackwell Publishers.

Fairclough N. (1995). Critical discourse analysis. London: Longman.

Fowler R. (1985). Power. In T.A. van Dijk (ed.), Handbook of Discourse Analysis, Vol.4. London: Academic Press, Inc. pp. 61-82.

Günther U. K. (2003). What's in a laugh? humour, jokes and laughter in the conversational corpus of the BNC. Albert Ludwigs Universität.

Halliday M.A.K. \& Matthiessen C.M.M. (2004). An Introduction to Functional Grammar. London: the Hodder Headline Group.

Inayah N. (2015). Power construction in english and buginese greetings. Makassar: Hasanuddin University. 
Krikmann A. (2006). Contemporary linguistic theories of humour. http://www.folklore.ee/folklore/vol33/kriku.pdf

Lillian D. L. (2008). Modality, persuasion and manipulation in Canadian conservative discourse. http://cadaad.org/ejournal, vol 2(1):1-16.

Lockyer S. \& Pickering M. (2008). You must be joking: the sociological critique of humour and comic media. Sociology Compass, 2 (3), pp. 808-820.

Palmer F. (2001). Mood and modality (2 nd edition). Cambridge: Cambridge University Press.

Rahimi F. \& Riasati M. J. (2011). Critical discourse analysis: scrutinizing ideologicallydriven discourses. Shiraz, Iran: Islamic Azad University.

Spradley J. P. (1980). Participant observation. USA: Macalester College.

Tracy S. J. (2013). Qualitative Research Method. UK: Blackwell Publishing.

Unger J. W. (2016). The interdisciplinarity of critical discourse studies research. UK: Lancaster University.

Wahdaniyah N. (2015). The intertextuality of kelong in si'ru dance of ganrang bulo performance. Makassar: Hasanuddin University.

Zelizer C. (2010). Laughing our way to peace or war: humour and peacebuilding. Journal of Conflictology, vol. 1(2). New Orleans. 